\title{
CONFOCAL MICRO-RAMAN SPECTROSCOPY: A POWERFUl TOOl TO IDENTIFY NATURAL AND SYNTHETIC EMERALDS
}

Le Thi-Thu Huong, Tobias Häger, and Wolfgang Hofmeister

More than 300 natural and synthetic emeralds from various sources were examined with confocal Raman spectroscopy. This method identifies different water types in the beryl channel sites, making it possible to determine whether an emerald is natural or synthetic. In addition, this approach can provide information regarding geographic origin or synthesis technique (flux or hydrothermal).

$\mathrm{T}$ o separate natural from synthetic emeralds, or determine the geographic origin of a natural stone or the growth technique of a synthetic, a gemologist can use microscopy, chemical analysis, and FTIR spectroscopy. Although there are varying degrees of overlap in features seen or analyzed, in many cases each method can lead to a good identification. Here we introduce another tool for determining emerald origin-confocal Raman spectroscopy. This method provides some distinct advantages over previous techniques. For example, traditional FTIR analysis requires that $2 \mathrm{mg}$ of material be pulverized and mixed with $\mathrm{KBr}$ powder (Schmetzer and Kiefert, 1990), and then the powder needs to be pressed into a thin disk, making this a destructive and time-consuming technique. Microscopic determination requires a trained and experienced gemologist, and is

See end of article for About the Authors and Acknowledgments. Gems \& Gemology, Vol. 46, No. 1, pp. 36-41.

(c) 2010 Gemological Institute of America only effective if the sample contains diagnostic inclusions. Chemical analysis can sometimes determine geographic origin as well as synthesis technique based on the concentrations of some minor or trace elements (e.g., Hänni, 1982; Schrader, 1983; Stockton, 1984; Yu et al., 2000). However, there is chemical overlap among some origins.

This article describes the use of confocal microRaman spectroscopy to classify water types in the structural channels of emeralds, to differentiate natural vs. synthetic emeralds (including the form of synthesis), and to investigate geographic origin (figure 1). Raman spectrometers with confocal capability are available in many gemological laboratories, and the analysis is rapid and nondestructive.

\section{BACKGROUND}

Beryl- $\mathrm{Be}_{3} \mathrm{Al}_{2} \mathrm{Si}_{6} \mathrm{O}_{18}$-has a structure that is composed of six-membered rings of $\left[\mathrm{SiO}_{4}\right]^{4-}$ tetrahedra. The $\mathrm{Si}_{6} \mathrm{O}_{18}$ rings are aligned precisely over one another, forming open channels parallel to the c-axis of the crystal (figure 2). The diameter of the channels is large enough to hold large ions and molecules such as alkalis and water (Goldman et al., 1978; Aines and Rossman, 1984).

For more than 40 years, water molecules in the structural channels of beryl have been classified by infrared spectroscopy. According to Wood and Nassau (1967, 1968), type I water molecules occur independently in the channels with their symmetry axis positioned perpendicular to the c-axis of the beryl crystal. Type II water molecules associate with nearby alkalis (mainly sodium) in the channels (again, see figure 2); as a result, the water molecule symmetry axis is parallel to the c-axis of the host 


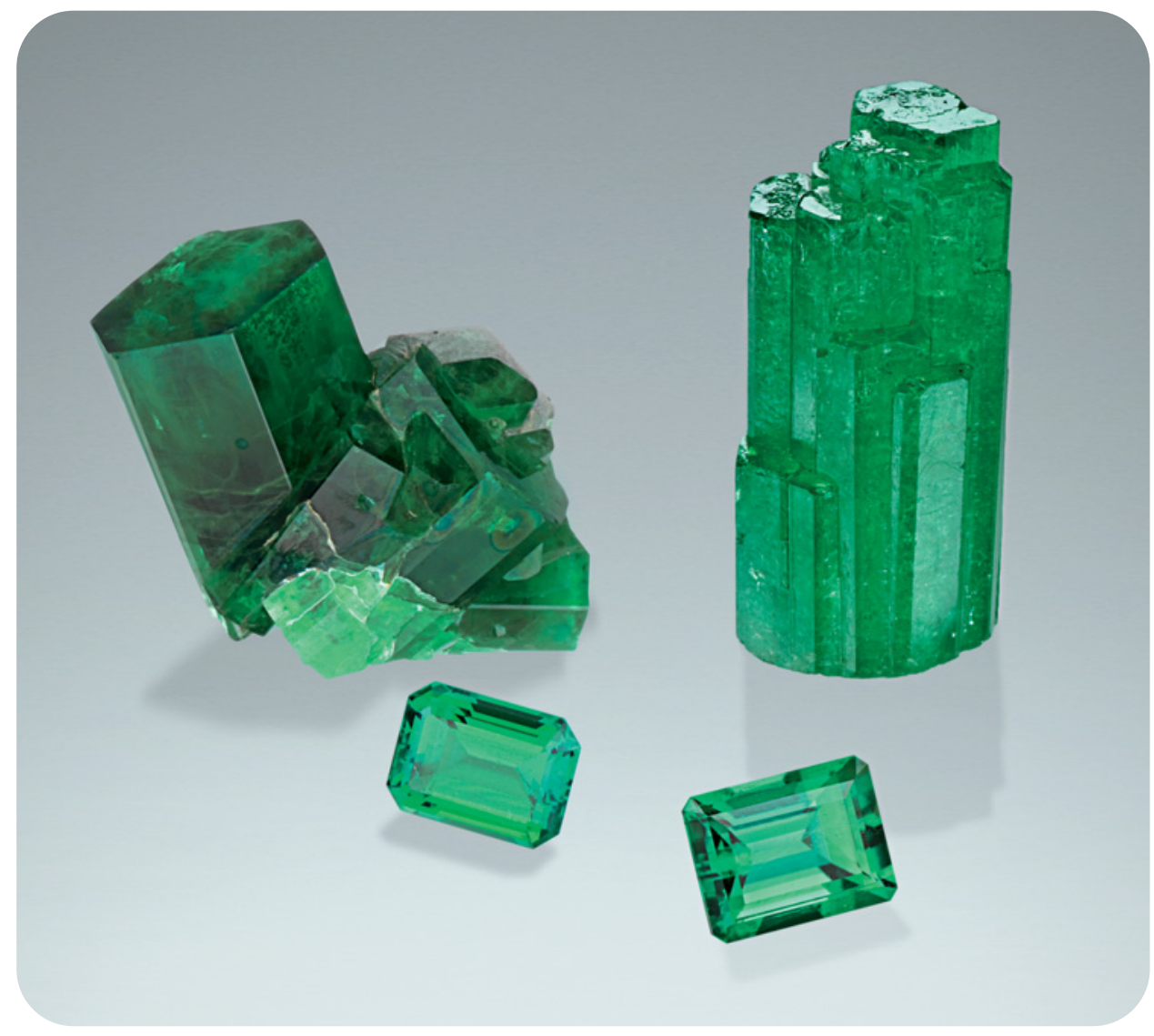

Figure 1. Natural and synthetic emeralds are available in the marketplace from a variety of sources. Shown here are a Gilson synthetic emerald crystal group (top left, $11.5 \mathrm{~g}$, GIA Collection no. 30490), a faceted Biron synthetic emerald (bottom left, 2.38 ct, GIA Collection no. 23523), a $10.9 \mathrm{~g}$ emerald crystal from Colombia (top right, courtesy of William Larson/Palagems.com), and a $4.50 \mathrm{ct}$ faceted emerald from Colombia's Chivor mine. Composite photo by Robert Weldon.

crystal (Schmetzer, 1989; Schmetzer and Kiefert, 1990). Aurisicchio et al. (1994) confirmed the existence of type I and type II water, and they also indi- cated that, in addition to $\mathrm{Na}^{+}$, the alkalis $\mathrm{K}^{+}$and $\mathrm{Cs}^{+}$ can occupy the channel positions of the beryl structure. The type and amount of water and associated

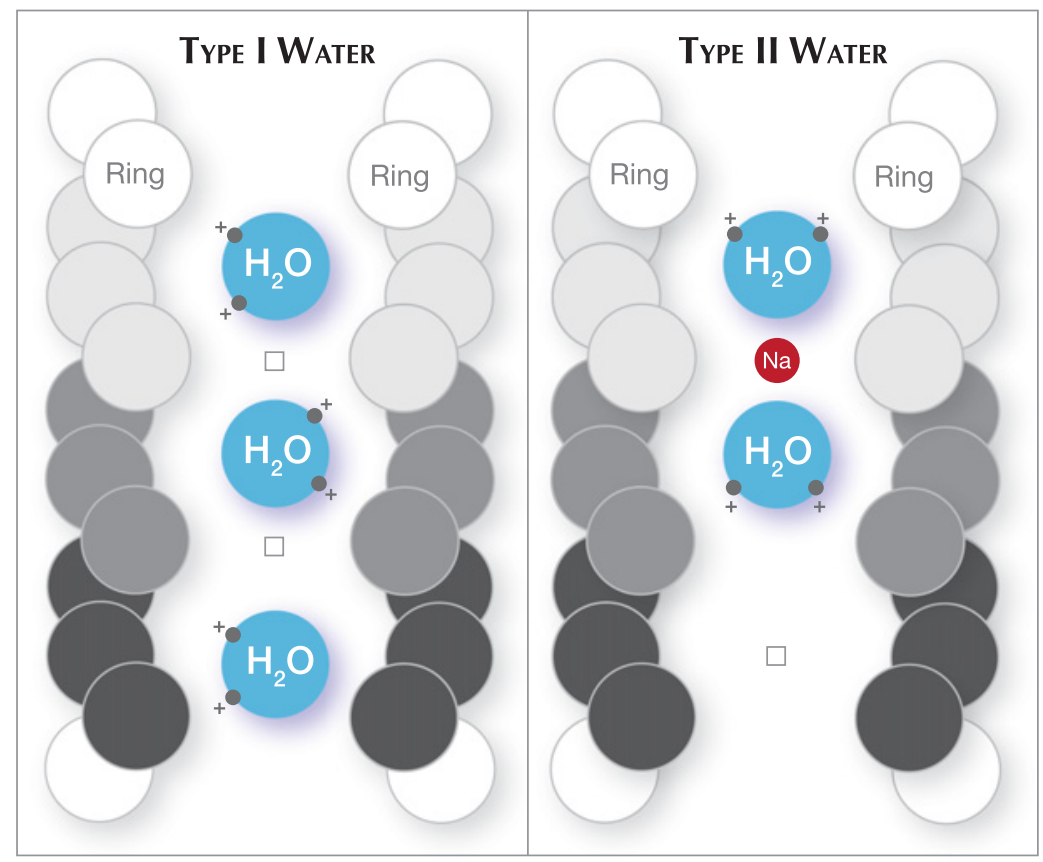

Figure 2. This view of the emerald structure looking approximately perpendicular to the c-axis shows the $\mathrm{Si}_{6} \mathrm{O}_{18}$ rings aligned precisely over one another, forming continuous, open channels that may hold large ions or molecules. Water molecules in the channels are classified as type I or type II according to their orientation relative to the beryl structure. Modified from Aurisicchio et al. (1994). 


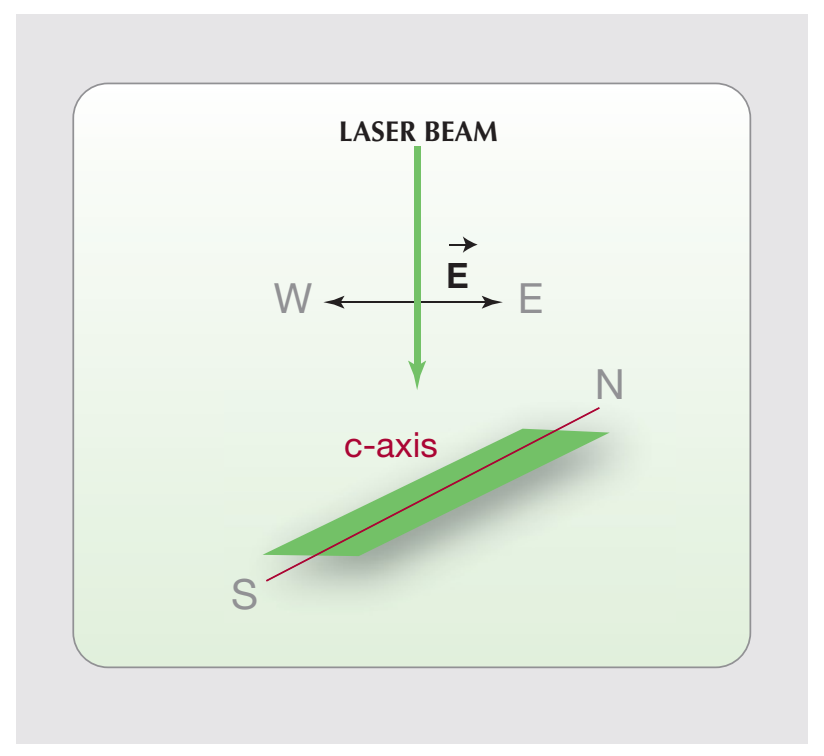

Figure 3. For Raman analysis, the sample is oriented so the c-axis of the crystal is perpendicular to the electric vector (E) of the laser beam.

alkalis in the beryl channel sites can provide valuable information for assessing the natural vs. synthetic origin of emeralds, as well as their geographic origin or method of manufacture.

\section{MATERIALS AND METHODS}

We collected 326 samples for Raman measurements, including 260 emerald crystals obtained directly from mines in Brazil (Carnaiba-15 samples, Capoeirana15, Itabira-15, Santa Terezinha-20, and Socotó15), Colombia (Chivor-30), Austria (Habachtal-10), Russia (Ural Mountains-10), Madagascar (Mananjary-30), South Africa (Transvaal-30), Zambia (Kafubu-30), Nigeria (Gwantu-30), and China (Malipo-10). In addition, 66 faceted synthetic emeralds consisting of hydrothermally grown (Tairus-15 and Biron-10) and flux-grown (Gilson-20, Chatham-20, and Lennix-1) samples were provided by the producers.

Raman spectra were collected from all samples at room temperature in the confocal mode. Confocal capability is necessary for Raman analysis of individual layers of a sample on a micron scale $(0.2-0.5 \mu \mathrm{m})$. We used a Jobin Yvon (Horiba group) LabRam HR 800 spectrometer equipped with an Olympus BX41 optical microscope and a Si-based CCD (charge-coupled device) detector. Spectra were collected in the range of $\mathrm{OH}^{-}$and water molecule vibrations (3700-3500 $\left.\mathrm{cm}^{-1}\right)$. The instrumentation used an $\mathrm{Ar}^{+}$ ion laser (514 nm emission), a grating of 1800 grooves $/ \mathrm{mm}$, and a slit width of $100 \mathrm{~mm}$. These parameters, and the optical path length of the spec- trometer, yielded a resolution of $0.8 \mathrm{~cm}^{-1}$. The spectral acquisition time was set at 240 seconds for all measurements, and sample orientation was carefully controlled. The electric vector of the polarized laser beam was always perpendicular to the c-axis (see figure 3). The polarization degree of the laser was about $98 \%$. Peak analysis was performed with an OriginLab 7.5 professional software package, and the peaks were fitted using a Gauss-Lorentz function.

Thirty-one of the crystals were chosen for chemical analysis of major and minor elements by electron probe microanalysis (EPMA; microprobe), and of minor/trace elements (including alkalis) by laser ablation-inductively coupled plasma-mass spec-

\begin{tabular}{|c|c|c|c|}
\hline Source & $\mathrm{Na}(w t . \%)$ & K (wt.\%) & $\mathrm{Na}+\mathrm{K}$ (wt.\%) \\
\hline \multicolumn{4}{|c|}{ Natural } \\
\hline $\begin{array}{l}\text { Colombia/Chivor } 1 \\
\text { Colombia/Chivor } 2 \\
\text { Colombia/Chivor } 3 \\
\text { Colombia/Chivor } 4 \\
\text { Colombia/Chivor } 5\end{array}$ & $\begin{array}{l}0.315 \\
0.296 \\
0.501 \\
0.657 \\
0.349\end{array}$ & $\begin{array}{l}0.008 \\
0.041 \\
0.006 \\
0.021 \\
0.047\end{array}$ & $\begin{array}{l}0.323 \\
0.337 \\
0.507 \\
0.678 \\
0.396\end{array}$ \\
\hline $\begin{array}{l}\text { Nigeria/Gwantu } 1 \\
\text { Nigeria/Gwantu } 2 \\
\text { Nigeria/Gwantu } 3 \\
\text { Nigeria/Gwantu } 4 \\
\text { Nigeria/Gwantu } 5\end{array}$ & $\begin{array}{l}0.093 \\
0.064 \\
0.070 \\
0.066 \\
0.070\end{array}$ & $\begin{array}{l}0.090 \\
0.069 \\
0.052 \\
0.029 \\
0.053\end{array}$ & $\begin{array}{l}0.183 \\
0.133 \\
0.122 \\
0.095 \\
0.123\end{array}$ \\
\hline $\begin{array}{l}\text { China/Malipo } 1 \\
\text { China/Malipo } 2\end{array}$ & $\begin{array}{l}0.773 \\
0.962\end{array}$ & $\begin{array}{l}0.123 \\
0.084\end{array}$ & $\begin{array}{l}0.896 \\
1.046\end{array}$ \\
\hline Brazil/Santa Terezinha & 1.452 & 0.102 & 1.554 \\
\hline Brazil/Socotó & 1.466 & 0.224 & 1.690 \\
\hline Brazil/Capoeirana & 1.329 & 0.316 & 1.645 \\
\hline Brazil/Carnaiba & 1.533 & 0.112 & 1.645 \\
\hline Brazil/Itabira & 1.466 & 0.323 & 1.789 \\
\hline $\begin{array}{l}\text { Russia/Ural } 1 \\
\text { Russia/Ural } 2\end{array}$ & $\begin{array}{l}1.035 \\
1.394\end{array}$ & $\begin{array}{l}0.712 \\
0.456\end{array}$ & $\begin{array}{l}1.747 \\
1.850\end{array}$ \\
\hline $\begin{array}{l}\text { Austria/Habachtal } 1 \\
\text { Austria/Habachtal } 2\end{array}$ & $\begin{array}{l}1.281 \\
1.327\end{array}$ & $\begin{array}{l}0.167 \\
0.230\end{array}$ & $\begin{array}{l}1.448 \\
1.557\end{array}$ \\
\hline $\begin{array}{l}\text { Madagascar/Mananjary } 1 \\
\text { Madagascar/Mananjary } 2\end{array}$ & $\begin{array}{l}1.053 \\
1.035\end{array}$ & $\begin{array}{l}0.057 \\
0.575\end{array}$ & $\begin{array}{l}1.110 \\
1.610\end{array}$ \\
\hline $\begin{array}{l}\text { Zambia/Kafubu } 1 \\
\text { Zambia/Kafubu } 2\end{array}$ & $\begin{array}{l}1.053 \\
1.065\end{array}$ & $\begin{array}{l}0.392 \\
0.481\end{array}$ & $\begin{array}{l}1.445 \\
1.546\end{array}$ \\
\hline $\begin{array}{l}\text { South Africa/Transvaal } 1 \\
\text { South Africa/Transvaal } 2\end{array}$ & $\begin{array}{l}1.065 \\
1.327\end{array}$ & $\begin{array}{l}0.610 \\
0.525\end{array}$ & $\begin{array}{l}1.675 \\
1.852\end{array}$ \\
\hline \multicolumn{4}{|c|}{ Synthetic (hydrothermal) } \\
\hline $\begin{array}{l}\text { Biron } 1 \\
\text { Biron } 2\end{array}$ & $\begin{array}{l}0.015 \\
0.016\end{array}$ & $\begin{array}{l}0.008 \\
0.004\end{array}$ & $\begin{array}{l}0.023 \\
0.020\end{array}$ \\
\hline $\begin{array}{l}\text { Tairus } 1 \\
\text { Tairus } 2\end{array}$ & $\begin{array}{l}0.007 \\
0.001\end{array}$ & $\begin{array}{l}0.005 \\
0.002\end{array}$ & $\begin{array}{l}0.012 \\
0.003\end{array}$ \\
\hline
\end{tabular}




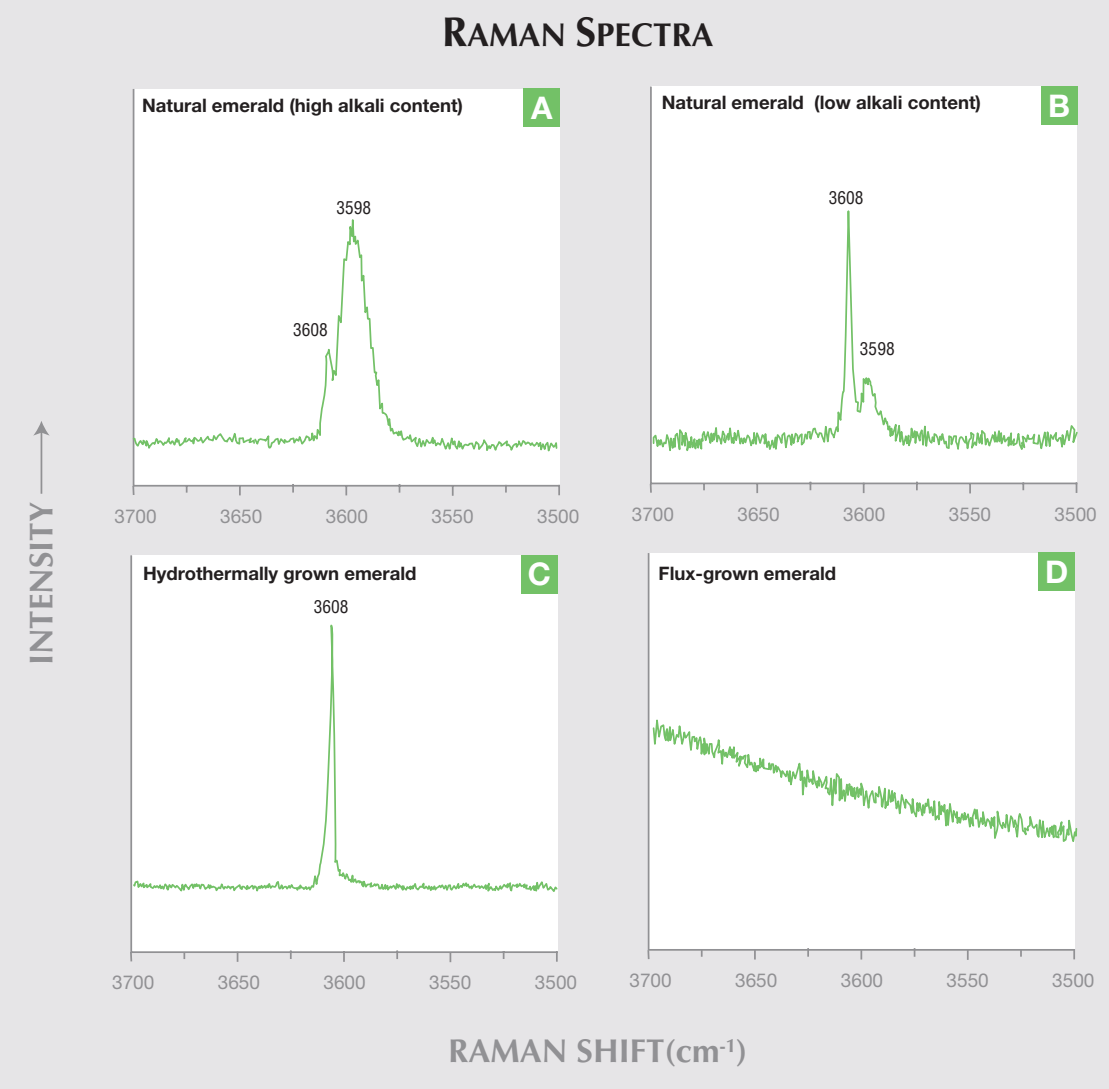

Figure 4. The Raman spectra of emeralds in the water range from 3700 to $3500 \mathrm{~cm}^{-1}(E \perp c)$ are shown here. Natural emeralds (A and $B$, representing samples from Austria and Nigeria, respectively) show two Raman bands, at 3608 and $3598 \mathrm{~cm}^{-1}$, with different intensities depending on alkali content. Hydrothermally grown synthetic emeralds $(C)$ show one Raman band, at $3608 \mathrm{~cm}^{-1}$, while flux-grown samples (D) do not display any Raman signal in this range other than the luminescence signal.

\section{NEED TO KNOW}

- Natural and synthetic emeralds from a variety of sources were examined with confocal Raman spectroscopy.

- The presence of Raman bands at 3608 and 3598 $\mathrm{cm}^{-1}$ is diagnostic of natural emeralds.

- Hydrothermal synthetics have only the $3608 \mathrm{~cm}^{-1}$ band, and flux-grown synthetics show neither band.

-The relative intensity of the two Raman bands in natural emeralds is determined by water type and alkali contents, and may be useful for assigning geographic origin.

trometry (LA-ICP-MS; table 1). No flux-grown samples were chemically analyzed because synthetic emeralds grown by this technique are devoid of channel constituents. Ablation was achieved with a
New Wave Research UP-213 Nd:YAG laser ablation system, using a pulse repetition rate of $10 \mathrm{~Hz}$ and $100 \mu \mathrm{m}$ crater diameters. Analyses were performed with an Agilent 7500ce ICP-MS in pulse counting mode (one point per peak and 10 milliseconds dwell time). Data reduction was carried out using Glitter software. The amount of material ablated in laser sampling varied in each spot analysis. Consequently, the detection limits were different for each spot and were calculated for each individual acquisition. Detection limits generally ranged between 0.001 and $0.5 \mathrm{ppm}$. Silicon (determined with the microprobe) was used as the internal standard. Analyses were calibrated against the silicate glass reference material NIST 612 using the values of Pearce et al. (1997), and the U.S. Geological Survey (USGS) glass standard BCR-2G was measured to monitor accuracy.

\section{RESULTS AND DISCUSSION}

As shown in figure 4, bands at 3608 and $3598 \mathrm{~cm}^{-1}$ were seen in the Raman spectra of all the natural emeralds, with varying relative intensity. The hydrothermally grown synthetic samples showed just 


\section{Raman Peak INTENSITY vs. AlKali COMPOSITION}

Figure 5. This diagram shows the intensity ratios of the two Raman peaks assigned to the two water types versus the alkali contents in the 31 samples for which chemical analysis was performed. The higher the alkali content in the sample, the greater the intensity ratio of the band at $3598 \mathrm{~cm}^{-1}$ to that at $3608 \mathrm{~cm}^{-1}$. This confirms that the $3598 \mathrm{~cm}^{-1}$ band is generated by water molecules associated with alkalis (type II), while the $3608 \mathrm{~cm}^{-1}$ band is related to water molecules without alkalis (type I).

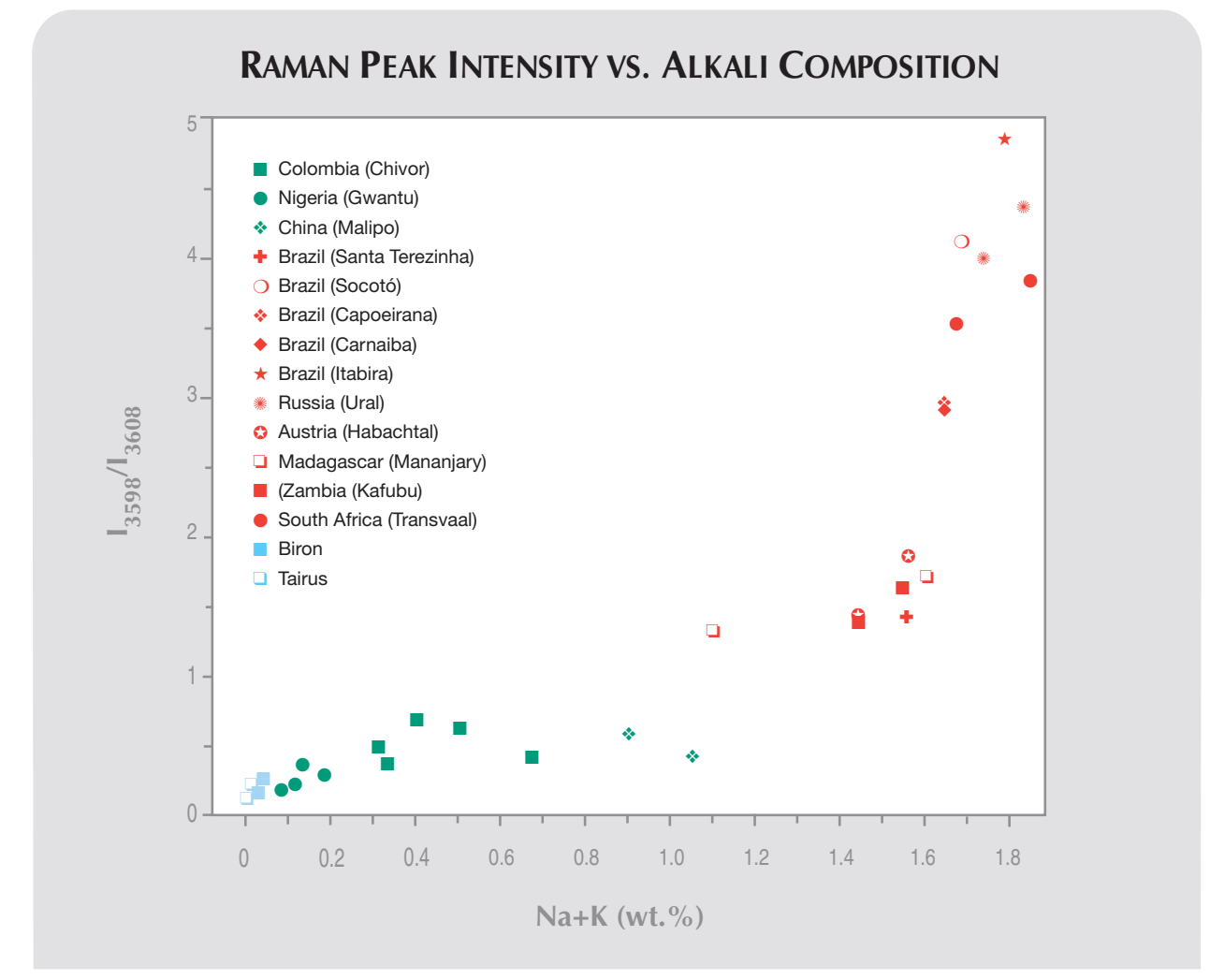

one band, at $3608 \mathrm{~cm}^{-1}$. None of the flux-grown synthetic samples showed distinct Raman bands in this range because they were anhydrous.

In the samples from Colombia and Nigeria, the band at $3598 \mathrm{~cm}^{-1}$ was less intense than that at 3608 $\mathrm{cm}^{-1}$ - that is, the $\mathrm{I}_{3598} / \mathrm{I}_{3608}$ ratio (where $\mathrm{I}$ is the peak intensity) was $<1-$ while in samples from all other localities, the $\mathrm{I}_{3598} / \mathrm{I}_{3608}$ ratio was $>1$ (figure 5 ). The Chinese samples had I $\mathrm{I}_{3598} / \mathrm{I}_{3608}$ ratios close to 1 .

From the chemical data reported by Hänni (1982), Schrader (1983), and Stockton (1984), and our data obtained by LA-ICP-MS (table 1), it was obvious that the presence and strength of the band at $3598 \mathrm{~cm}^{-1}$, as well as the $\mathrm{I}_{3598} / \mathrm{I}_{3608}$ ratio, depend on the amount of alkali ions. The $3598 \mathrm{~cm}^{-1}$ band was detected only in the alkali-containing (natural) emeralds. In the nearly alkali-free samples (hydrothermal synthetics), this band disappeared while the $3608 \mathrm{~cm}^{-1}$ band persisted.

Figure 5 provides a good illustration of how the $3598 \mathrm{~cm}^{-1}$ band increased in intensity (relative to the $3608 \mathrm{~cm}^{-1}$ band) according to alkali content. For example, in high-alkali samples such as emeralds from Brazil's Socotó mine, with up to $1.7 \mathrm{wt}$.\% alkalis, the $\mathrm{I}_{3598} / \mathrm{I}_{3608}$ ratio exceeded 4. In low-alkali samples, such as emeralds from Colombia's Chivor mine, with $\sim 0.4$ wt. \% alkalis, the $\mathrm{I}_{3598} / \mathrm{I}_{3608}$ ratio was about 0.7. Since emeralds from different localities contain different amounts of alkalis, this Raman technique appears useful for fingerprinting geographic origin (although there was some overlap in our samples from certain localities).

The Raman band at $3598 \mathrm{~cm}^{-1}$ is therefore here assigned to the vibration of type II water molecules, because it occurred exclusively in samples containing alkalis, and the Raman band at $3608 \mathrm{~cm}^{-1}$ is ascribed to the vibration of type I water. These Raman signals from the different types of water molecules in the beryl channels appear to provide diagnostic evidence for establishing if a sample is natural, flux grown, or hydrothermally grown: In natural emeralds both bands are visible, in hydrothermally grown samples only the $3608 \mathrm{~cm}^{-1}$ band is seen, and in flux-grown synthetic emeralds neither of these bands is visible.

\section{CONCLUSION}

This study used nondestructive confocal microRaman spectroscopy to distinguish natural and synthetic emeralds as well as emeralds synthesized by flux and hydrothermal methods. The technique also appears useful for investigating the geographic origin of natural emeralds, although additional samples from various known localities should be investigated to further evaluate its effectiveness. 
ABOUT THE AUTHORS

Dr. Le Thi-Thu Huong (letth@vnu.edu.vn) is a lecturer in mineralogy at the Faculty of Geology, Hanoi University of Science, Vietnam. Prof. Dr. Hofmeister is dean of the Faculty of Chemistry, Pharmacy and Geosciences, and head of the Centre for Gemstone Research, at Johannes Gutenberg University, Mainz, Germany. He is also head of the Institute of Gemstone Research in Idar-Oberstein, Germany. Dr. Häger is senior scientist at the Centre for Gemstone Research at Johannes Gutenberg-University, lecturer in the Gemstone and Jewellery Design Department at the University for Applied Sciences in Idar-Oberstein, and managing director of the Institute of Gemstone Research in Idar-Oberstein.

\section{ACKNOWLEDGMENTS}

This research was financed by the Johannes Gutenberg University Fund for Gemstone Research. Analytical facilities were provided by the Institute of Geology at Johannes Gutenberg University. The authors are grateful for the support.

\section{REFERENCES}

Aines R.D., Rossman G.R. (1984) The high temperature behavior of water and carbon dioxide in cordierite and beryl. American Mineralogist, Vol. 60, pp. 319-327.

Aurisicchio C., Grubessi O., Zecchini P. (1994) Infrared spectroscopy and crystal chemistry of the beryl group. Canadian Mineralogist, Vol. 32, pp. 55-68.

Goldman D.S., Rossman G.R., Parkin K.M. (1978) Channel constituents in beryl. Physics and Chemistry of Minerals, Vol. 3, pp. 225-235.

Hänni H.A. (1982) A contribution to the separability of natural and synthetic emeralds. Journal of Gemmology, Vol. 18, No. 2, pp. 138-144.

Pearce N.J.G., Perkins W.T., Westgate J.A., Gorton M.P., Jackson S.E., Neal C.R., Chenery S.P. (1997) A compilation of new and published major and trace element data for NIST SRM 610 and NIST SRM 612 glass reference materials. Geostandards Newsletter, Vol. 21, pp. 115-144.

Schmetzer K. (1989) Types of water in natural and synthetic emer- ald. Neues Jahrbuch für Mineralogie, Monatshefte, No. 1, pp. $15-26$.

Schmetzer K., Kiefert L. (1990) Water in beryl—A contribution to the separability of natural and synthetic emeralds by infrared spectroscopy. Journal of Gemmology, Vol. 22, No. 4, pp. 215-223.

Schrader H.W. (1983) Contribution to the study of the distinction of natural and synthetic emeralds. Journal of Gemmology, Vol. 19 , No. 6, pp. 530-543.

Stockton C.M. (1984) The chemical distinction of natural from synthetic emeralds. GÆ G, Vol. 23, No. 2, pp. 141-145.

Wood D.L., Nassau K. (1967) Infrared spectra of foreign molecules in beryl. Journal of Chemical Physics, Vol. 47, No. 7, pp. $2220-2228$.

Wood D.L., Nassau K. (1968) The characterization of beryl and emerald by visible and infrared absorption spectroscopy. American Mineralogist, Vol. 53, pp. 777-800.

Yu K.N., Tang S.M., Tay T.S. (2000) PIXE studies of emeralds. $X$ ray Spectrometry, Vol. 29, pp. 267-278.

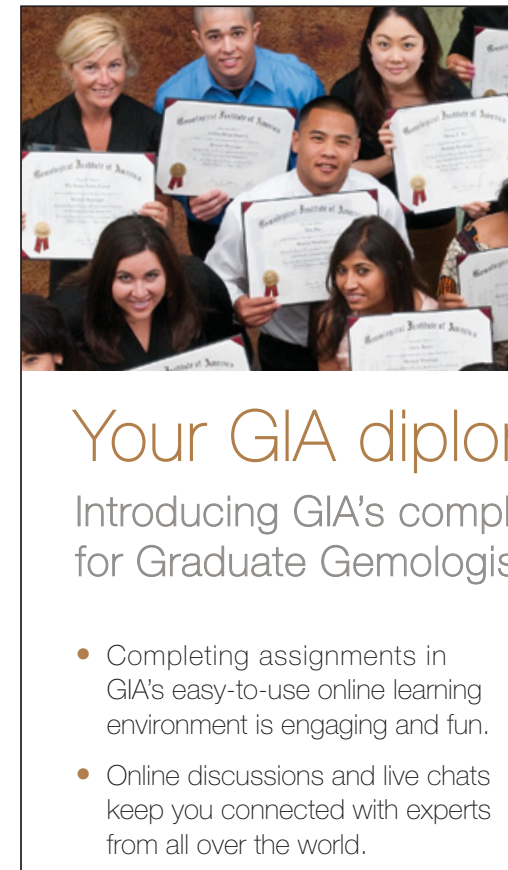

from all over the world.
- Access to all GIA eLearning gemology course materials keeps an entire gem and jewelry reference library right at your fingertips.

- Affordable \$189 annual fee, or bundle it with a $G \& G$ online subscription for just $\$ 60$ more.

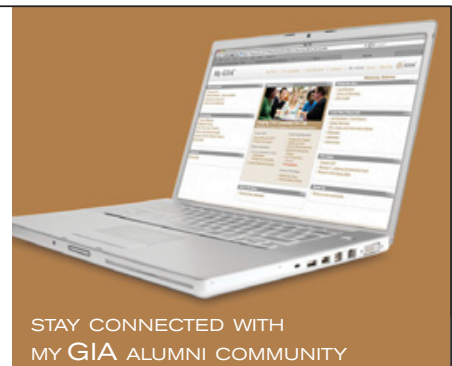

MY GIA ALUMNI COMMUNITY 